\title{
IAMJ
}

INTERNATIONAL

AYURVEDIC

MEDICAL JOURNAL

[d] 10

\section{A COMPARATIVE STUDY OF GOMUTRA HARITAKI VATI AND MUSTADI VATI IN THE MANAGEMENT OF STHAULYA (W.S.R. TO OBESITY)}

\section{Vaidya Bharat Mungara ${ }^{1}$ Vaidya Priya Kodrani ${ }^{2}$}

${ }^{1}$ Asso. Prof. Kayachikitsa Dept., Government Ayurved College, Junagadh, Gujarat, India

${ }^{2}$ Lecturer, Kayachikitsa Dept. V.N. Mehta Ayurvedic College, Anandpar, Rajkot, Gujarat, India

Email: patanjaliayucare@yahoo.com

\section{https://doi.org/10.46607/iamj0807072020}

(Published online: July 2020)

Open Access

(C) International Ayurvedic Medical Journal, India 2020

Article Received: 15/06/2020 - Peer Reviewed: 22/06/2020 - Accepted for Publication: 01/07/2020

\section{Check for updates}

\section{ABSTRACT}

Sthaulya (Obesity) is among the diseases which are increasing in prevalence day by day. It is important to rule out it on time and get cured. Symptoms and complications of it have effect on daily work efficiency. This study was carried out on 30 patients having classical symptoms of Sthaulya. Patients were selected as per the inclusion, exclusion and diagnostic criteria. Patients were divided into two groups randomly. Group A was treated with Gomutra haritaki vati and Group B was treated with Mustadi vati for 8 weeks. Grade score were adopted for the assessment of the symptoms. The obtained data were analyzed statistically. Probable action of Gomutra haritaki vati might be Srotobandh nashana, Malashodhana and Aamapaachana while of Mustadi vati might be Dhatushoshana, Rukshana, Lekhana. Thus, both drugs have beneficial effect in treating Sthaulya. This study includes 30 patients. In Group A, 20\% patients were 100\% cured, 66.66\% had marked improvement and 13.33\% patients had moderate improvement. In group B, 40\% patients were $100 \%$ cured, $40 \%$ patients had marked improvement, 20\% patients had moderate improvement. Group A showed 84.12\% result while Group B showed $82.07 \%$ result.

Keywords: Gomutra haritaki vati, Mustadi vati, Obesity, Sthaulya

\section{INTRODUCTION}

Sthaulya (Obesity) is one among the major diseases of Modern era. In Modern era with continuous 
changing lifestyles and environment, changed diet habits, man has become the victim of many disease caused by unwholesome dietary habits and obesity is one of them. Industrialization, stress during work, faulty dietary habits, lack of exercise \& various varieties among the daily diet e.g. fast food, frozen fruits, increased amount of soft drinks and beverages, canned foods results into the clinical entity which we can call as obesity. Ayurveda has identified obesity as a disorder very early. Acharya Charaka have listed eight types of censurable persons of which Atikrusha (very emaciated) and Atisthula (very corpulent) are more significant. ${ }^{[1]}$ Atisthula or obese persons need more attention because they are considered as kruchchha sadhya and has more complications than very emaciated person ${ }^{[2]}$ Acharya Charaka have given a line of treatment of sthaulya, "गुरु चापतपर्ण”, means drugs or food which are guru in nature but karshyakarak are useful to treat obese person. ${ }^{[3}$ ] Sthaulya is also mentioned as one of the Santarpanajanya vyadhi by Acharya Charaka ${ }^{[4]}$ and under its treatment Mustadi Kwath is given. ${ }^{[5]}$ In these era of injectables, tablets and capsule, kwath formulation is time consuming to make every day and tough to take. So to assess the apatarpak effect of this medicine, it is selected and to make it easy for patients, transformed in tablet form. Acharya Sushruta have mentioned Gomutra \& Haritaki in the treatment of Sthaulya ${ }^{[6]}$ So it is selected for another group to compare and in same fashion, transformed in tablet form.

\section{Aim \& Objectives:}

- To evaluate the comparative effect of Gomutra haritaki vati and Mustadi vati in the management of Sthaulya.

- To evaluate the efficacy of Gomutra haritaki vati in the management of Sthaulya.

- To evaluate the efficacy of Mustadi vati in the management of Sthaulya.

\section{Materials and methods:}

In the present study 30 patients fulfilling the criteria for diagnosis of the disease were selected from the OPD of Kayachikitsa department, Govt. Akhan- danand Ayurved college and hospital, Ahmedabad. The research protocol was approved by Institutional Ethics committee (Vide Certi. No. 51; date: 13/07/2016) and registered in Clinical Trials Registry of India (CTRI/2017/05/008659; date: 25/05/2017).

An informed consent from each enrolled patient was obtained before commencement of the treatment. The patients were selected irrespective of their age, sex, religion, occupation etc. and simple random sampling technique was followed for grouping the patients in two groups.

\section{Diagnostic criteria:}

Classical signs \& symptoms of the disease as mentioned in the Ayurvedic texts as well as modern books and BMI measurement were taken as diagnostic criteria for the present study.

\section{Inclusion criteria:}

Patients between the age group of 18-50 years with signs \& symptoms of Sthaulya (obesity) were selected. Patients having BMI (Body Mass Index) more than 25 and $\leq 35$ were taken for the study. [Pre obese (BMI 25-29.99) and obese class I (BMI 30-34.99) according to $\mathrm{WHO}$ criteria of weight for height were taken for study.]

\section{Exclusion criteria:}

Patients suffering from Pulmonary diseases, Cardiac diseases, Hypothyroidism, Hypertension, PCOD, HIV and diseases which leads to fatal condition were not taken for the study. Patients having B.M.I. more than 35 were excluded.

\section{Investigations:}

- CBC, ESR

- Urine- Routine and microscopic

- FBS, PPBS

- Lipid Profile

- T3, T4, TSH

- P.C.O.D. Panel

Above and other pathological and biochemical investigations were conducted as per need to ex- clude other pathology and facility available in the institute.

\section{Grouping and Posology:}

Patients including in the present study are randomly divided into following groups:

Group -A 
- Drug: Gomutra haritaki vati

- Dose: 5 tablets two times (each tablet of $500 \mathrm{mg}$ )

- Mode of administration: Oral

- Time of administration: Empty stomach twice a day at morning and evening.

- Anupan: Ushnodaka.

- Duration: 8 Weeks.

Group -B

- Drug: Mustadi vati

- Dose: 5 gms/ day in tablet form in two divided doses (each tablet of 500mg)

- Mode of administration: Oral

- Time of administration: Empty stomach twice a day at morning and evening.

- Anupan: Ushnodaka

- Duration: 8 Weeks

Dietary regimen: Patients were advised to follow the diet and exercise described as Pathya for Sthaulya (obesity) in Ayurvedic classics and to avoid all the causative factors as apathya during the whole treatment.

\section{Informed consent:}

The purpose of the study, nature of the study drugs, the procedures to be carried out and the poten- tial risk and benefits were explained to the patients in details in non-technical terms and trilingual. There after their consent was taken.

\section{Criteria for assessment:}

The efficacy of the therapy was assessed on the basis of improvement observed in subjective and objective criteria, by giving them appropriate scoring according to the scoring pattern before and after treatmentSubjective criteria:

- Cardinal symptoms: Bharvriddhhi, Chala sphikaudara-stana, Ayathopachayotsah, Javoparodha, Kruchchha vyavayata, Daurbalya, Daurgandhya, Swedabadh, Atikshudha, Atipipasa.

- Associated symptoms: Gatra gaurava, Kshudra shwasa, Gatrasada, Snigdha gatrata, Anga Shaithilya.

\section{Objective criteria:}

1. Weight: Therapy was assessed by measuring weight of patients before and after treatment on the same electronic weight machine.

2. BMI: The BMI criteria of weight for height according WHO was adopted in the present work.

Table 1: Overall effect of therapy:

\begin{tabular}{|l|l|}
\hline Effect & Percentage relief in symptoms \\
\hline Completely cured & $100 \%$ relief in signs and symptoms \\
\hline Marked improvement & $>75 \%$ to $99 \%$ relief in signs and symptoms \\
\hline Moderate improvement & $>50 \%-75 \%$ relief in signs and symptoms \\
\hline Mild improvement & $>25 \%-50 \%$ relief in signs and symptoms \\
\hline
\end{tabular}

\section{Results And Interpretation:}

The obtained results were subjected to suitable statistical analysis that described in detail given below;

1. Descriptive statistics for demographic data.

2. Wilcoxon Signed Rank test for non-parametric paired data.

3. Mann Whitley Sum Rank test for non-parametric unpaired data know the significance of com- parison between groups.

4. Paired t-test: for quantitative parametric paired data.

5. Un-paired t-test: for quantitative parametric unpaired data.
The results were interpreted as.

- Insignificant: $\mathrm{p}>0.05$

- Significant: $\mathrm{p}<0.05$

- Highly Significant: $p<0.001$

The presentation of data has been made in the following order:

1. General observations including age, sex, diet, lifestyle etc.

2. Results of the therapy - this part comprises of results on.

- Objective criteria

- Subjective criteria

- Overall effect of therapy 


\section{Observations and Results:}

Total 30 patients were registered for the present study and were randomly divided into two groups to evaluate the role of Gomutra haritaki vati and Mustadi vati in the management of Sthaulya. Maximum patients i.e. $63.33 \%$ were from $18-30$ years of age group. The prevalence of disease was found higher in females $(76.66 \%)$. Maximum patients were housewife $(43.33 \%)$ and belong to upper middle class $(56.66 \%)$. It may be due to aggravating factors like sedentary life style, lack of proper exercise, over eating, pregnancy, menopause, oral contraceptive as well as I.U.C.D etc.Maximum patients i.e. $90 \%$ were having outside food once in a week and refreshments between two meals. Adhyashana is mentioned as the root cause by Acharya Sushruta. Maximum patients were practicing Madhura rasa (76.66\%), Guru (83.33\%), Snigdha (86.66\%) and Sheeta bhojana $(56.66 \%)$. These properties aggravate the Kapha Dosha and increase the Meda dhatu. Maximum i.e.50\% had habit of water intake after meal. Bhojanottara jalapana is bruhanakaraka. Lack of Vyayama and Divaswapa are main causes of obesity. Avyayama was found in $83.33 \%$ patients, Avyavaya and Sukashayanam in $76.66 \%$ while Divaswapa in $63.33 \%$ patients. $73.33 \%$ patients were jolly in nature and Achinta was found in 56.66\%. Beejadosha was found in only $30 \%$ patients. Among 30 patients, Bharvriddhi was found in all (100\%) patients. Atipipasa was observed in $90 \%$ patients. Chala sphik-udara-stana was observed in $83.33 \%$ patients. Swedabadh was ob- served in $80 \%$ patients. Atikshudha was observed in $76.66 \%$ patients. Ayathopachayotsah and Dau- rgandhya were observed in $66.66 \%$ patients. Daurbalya was observed in $63.33 \%$ patients. Javoparodha was observed in $53.33 \%$ patients. Kruchchha vyavayata, Kshudra shwasa, Angshaithilya and Snigdha gatrata were observed in few patients. Mostly adult and gradual onset obesity and progressive course of obesity was seen.

\section{Effect of therapies on Subjective criteria:}

Patients in Group A showed 65\% relief in Bharvruddhi while in Group B, 68.42\%relief was marked. Both drugs have statistically highly significant result on Bharvruddhi $(\mathrm{p}<0.001)$. Patients in Group A showed $73.07 \%$ relief in Chala sphika udar stana while in Group B, 66.66\% relief was marked in Chala sphika udar stana. Both drugs have statistically highly significant result on Chala sphika udar stana. Patients in both Groups showed 100\% relief in Ayathopachayotsah. Both drugs have statistically highly significant result on Ayathopachayotsah $(\mathrm{p}<0.001)$. Patients in Group A showed 90\% relief in Javoparodha, while in Group B, 100\% relief was marked. Both drugs have statistically highly significant result on Javoparodha. Patients in Group A showed 50\% relief in kruchchha vyavayata, while in Group B, 85.71\% relief was marked. Both drugs have statistically significant result on kruchchha vyavayata $(\mathrm{p}<0.05$, due to small number of patients). Patients in both Groups showed $100 \%$ relief in Daurbalya, Group A showed statistically significant result $(\mathrm{p}<0.05)$ while Group B showed statistically highly significant result on Daurbalya. Patients in Group A showed 80\% relief in Daurgandhya, while in Group B, 100\% relief was marked in Daurgandhy. Group A showed statistically significant result on Daurgandhya ( $\mathrm{p}<0.05$ ) while Group B showed statistically highly significant result on Daurbalya $(\mathrm{p}<0.001)$.

\section{Effect of therapies on Objective criteria:}

In Group A, reduction in weight was noted about $6.716 \%$ while in Group B, it was $6.072 \%$. Both drugs showed statistically highly significant result on weight reduction $(\mathrm{p}<0.001)$. In Group A, reduction in BMI was noted about $6.758 \%$ while in Group B, it was $6.052 \%$. Both drugs showed statistically highly significant result on BMI $(\mathrm{p}<0.001)$.

\section{Overall effect of therapy}

In Group A, 20\% patients were 100\% cured, $66.66 \%$ had marked improvement and $13.33 \%$ patients had moderate improvement. In group B, $40 \%$ patients were $100 \%$ cured, $40 \%$ patients had marked improvement, $20 \%$ patients had moderate improvement. Group A showed $84.12 \%$ result while Group B showed $82.07 \%$ result. Thus, Group A showed minimal better result than Group B. 
Table 2: Shows Overall effect of therapy

\begin{tabular}{|l|l|l|l|l|}
\hline \multirow{2}{*}{ Overall Effect } & Group A & Group B \\
\cline { 2 - 5 } & No. of pt & \% of pt & No. of pt & $\%$ of pt \\
\hline Completely cured & 3 & $20 \%$ & 6 & $40 \%$ \\
\hline Marked improvement & 10 & $66.66 \%$ & 6 & $40 \%$ \\
\hline Moderate improvement & 2 & $13.33 \%$ & 3 & $20 \%$ \\
\hline Mild improvement & 0 & 0 & 0 & 0 \\
\hline No improvement & 0 & 0 & 0 & 0 \\
\hline
\end{tabular}

Table 3: Comparison of both groups

Total effect of therapy

\section{DISCUSSION}

Probable mode of action of Gomutra haritaki vati:

It was noted that Gomutra haritaki had mild to moderate virechana effect. It is known that Haritaki has Anulomana effect, so hypothetically it can be said that with Bhavna of Gomutra, Haritaki has Virechana effect. By Vatanulomana and Malashodhana due to virechana effect, the provoked Jatharagni is normalised and appetite is controlled. Katu, Tikta, Kashaya Rasa pradhanya ${ }^{7}$ and Laghu, Ruksha, Tikshna and Ushna Guna pradhanya ${ }^{8}$ and Ushna veerya are indicative of Kaphashamaka effect of this drug. Qualities of Gomutra and Haritaki are opposite to the Meda dhatu. Again, Haritaki is Kashaya rasa pradhana drug. Kashaya Rasa is the most Ruksha amongst the six Rasa. By the virtue of its Shoshana property, it absorbs the Meda dhatu, Kleda, Sweda and Kapha Dosha. It also aids in removing excess Kleda present in the body by performing Kledaharana.

So, Gomutra haritaki vati may augment the Agni and digest the Aama, Malashodhana by virechana effect.further it break the obstruction of srotasa and enhance the prakruta dhatuposhana krama.By absorbing the excessive Meda dhatu as well as Kleda, Sweda, Vasa and it reverse the pathology.and helps to prevent the complications of Sthaulya.

\section{Probable mode of action of Mustadi vati:}

Aragvadha and Triphala have mild purgative action which causes Anulomana of Vayu which further corrects the perverted Vayu bringing an end to the
Vatapradhana Samprapti. Musta, Patha, Triphala, Nimba, Khadira, Haridra, Daruharidra and Vatsaka are having Kaphashamaka properties. Kapha dosha acts as poshaka to the samprapti cycle of the disease because at the beginning, it is Sama Kapha which converts into Aama dosha and obstructs srotasa. An ideal treatment is not to stop the cycle but to cut it from the root. So Mustadi vati cut it from the root and cure. This drug relieves the body with excess of Kapha, Meda, Kleda, Vasa and Sweda by diminishing their Drava Guna. Drugs like Patha and Gokshura 9 are Mutravirechana which bring about diuresis relieving the body from excess of Kleda. Also, drugs like Triphala ${ }^{10}$, Khadira are Rasayana in nature which lead to formation of optimal dhatu and protect the body from injury due to vitiated Dosha. Along with that, probable Karma of Mustadi vati is Lekhana, Dhatushoshana, Kledashoshana etc. To get rid of inordinately excessive Meda dhatu, Lekhana and Rukshana are only helpful upakrama. Aama dosha which is the main cause of Dhatvagnimandhya and is digested and eliminated by Mustadi vati.

In summery Mustadi vati digest the Aama dosha and correct the Jatharagni and Medodhatvagni, correct the Vata dosha by Anulomana and control the increased appetite; correct the Kapha dosha and stop the formation of Aama; clear the srotasa by Dhatushoshana and Kledashoshana karma; diminish the Meda dhatu by Lekhana and Rukshana karma that lead to the optimal dhatu formation by $R a$ sayana karma. 


\section{CONCLUSION}

Sthaulaya is Dushyapradhana vyadhi. Medodhatu plays major role in it, so correction of Dosha only cannot be helpful. Description given in our text specifically in Charak Samhita is far enough and scientific to understand the disease. Losing the weight is not the treatment, losing the lifestyle that increased the weight is the treatment of Sthaulaya. Most of the patients were following dietary regimen but very irregular in exercise. At the end of the study, it was concluded that Gomutra haritaki vati and Mustadi vati have equal effect in the management of Sthaulya.

\section{REFERENCES}

1. Charaka Samhita composed by Maharshi Agnivesha, revised by Charaka and Dradhabala, Hindi translation along with prose order of text and Eshana Hindi translation of Ayurvedadipika Comm. of Shri Chakrapanidatta, translated by Prof. Banwari Lal Gaur and Prof. Radheshyam Kalavatiya, edited by Prof. Vaidya V. V. Prasad, published by Rashtriya Ayurveda Vidyapeeth, Delhi, 2011, vol. 1, Sutrasthana 21/4; 626

2. Charaka Samhita composed by Maharshi Agnivesha, revised by Charaka and Dradhabala, Hindi translation along with prose order of text and Eshana Hindi translation of Ayurvedadipika Comm. of Shri Chakrapanidatta, translated by Prof. Banwari Lal Gaur and Prof. Radheshyam Kalavatiya, edited by Prof. Vaidya V. V. Prasad, published by Rashtriya Ayurveda Vidyapeeth, Delhi, 2011, vol. 1, Sutrasthana 21/17;631

3. Charaka Samhita composed by Maharshi Agnivesha, revised by Charaka and Dradhabala, Hindi translation along with prose order of text and Eshana Hindi translation of Ayurvedadipika Comm. of Shri Chakrapanidatta, translated by Prof. Banwari Lal Gaur and Prof. Radheshyam Kalavatiya, edited by Prof. Vaidya V. V. Prasad, published by Rashtriya Ayurveda Vidyapeeth, Delhi, 2011, vol. 1, Sutrasthana 21/20;633

4. Charaka Samhita composed by Maharshi Agnivesha, revised by Charaka and Dradhabala, Hin- di translation along with prose order of text and Eshana Hindi translation of Ayurvedadipika Comm. of Shri Chakrapanidatta, translated by Prof. Banwari Lal Gaur and Prof. Radheshyam Kalavatiya, edited by Prof. Vaidya V. V. Prasad, published by Rashtriya Ayurveda Vidyapeeth, Delhi, 2011, vol. 1, Sutrasthana 23/6; 662
5. Charaka Samhita composed by Maharshi Agnivesha, revised by Charaka and Dradhabala, Hin di translation along with prose order of text and Eshana Hindi translation of Ayurvedadipika Comm. of Shri Chakrapanidatta, translated by Prof. Banwari Lal Gaur and Prof. Radheshyam Kalavatiya, edited by Prof. Vaidya V. V. Prasad, published by Rashtriya Ayurveda Vidyapeeth, Delhi, 2011, vol. 1, Sutrasthana 23/12,13; 664

6. Sushruta Samhita of Sushruta, with Nibandhasangraha Comm. of Shri Dalhanacharya, edited by Vaidya Jadavji Trikamji Acharya, Chaukhamba Sanskrit Sansthan, Varanasi, 2015, Sutrasthana, 15/32; 73

7. Agnivesha, Charaka, Dridhabala, Charakasamhita, edited by Yadavji trikamji Acharya, Reprint, Chaukhambha surabharati prakashana, Varanasi, 2011, Sutrasthana 26/43; 144-145

8. Bhavamishra, Bhavaprakashasamhita, edited by Pandit Shri Brahma Sankar Mishra with the Vidyotani Hindi Commentary, Chaukhambha Sanskrit Sansthan, Varanasi,9th Edition, 2005, Purva khanda, Misra prakaran 6/202-211;189-190

9. Agnivesha, Charaka, Dridhabala, Charakasamhita, edited by Yadavji trikamji Acharya, Reprint, Chaukhambha surabharati prakashana, Varanasi, 2011, Sutrasthana $4 / 15,33$

10. Anonymous, Dhanvantari nighantu, Misra varga $7 / 2$, edited by Prof. Priyavrat sharma,4th Edition, Chaukhambha Orientalia, Varanasi, $2005 ; 260$

\section{Source of Support: Nil Conflict of Interest: None Declared}

How to cite this URL: Vaidya Bharat Mungara \& Vaidya Priya Kodrani: A Comparative Study Of Gomutra Haritaki Vati And Mustadi Vati In The Management Of Sthaulya (W.S.R. To Obesity). International Ayurvedic Medical Journal \{online\} 2020 \{cited July, 2020\} Available from: http://www.iamj.in/posts/images/upload/3863 3868.pdf 